\title{
The serum levels of the cytokines involved in the Th17 and Th1 cell commitment are increased in individuals with borderline thrombocytopenia
}

\author{
Andreia Maria Camargos Rocha', Cláudia Souza², Gifone Aguiar Rocha' ${ }^{1}$, Fabrício Freire de Melo ${ }^{1,3}$, \\ Nelma Cristina Diogo Clementino ${ }^{2}$, Marília Campos Abreu Marino ${ }^{4}$ and Dulciene Maria Magalhães Queiroz ${ }^{1 *}$
}

\begin{abstract}
The definition of immune Thrombocytopenia (ITP) as a peripheral blood platelet count less than $100 \times 10^{9} / \mathrm{L}$ instead of the historical criteria of $150 \times 10^{9} / \mathrm{L}$ renders subjects with platelets between 100 and $150 \times 10^{9} / \mathrm{L}$ without a diagnosis. Here, we demonstrated that these subjects have enhanced levels of proinflammatory cytokines linked to Th1 and Th17 cell response, and are more frequently carriers of polymorphisms in genes that code cytokines involved in the commitment of Th1 and Th17 immune response, when compared with controls, similarly to that observed in patients with ITP.
\end{abstract}

Keywords: Thrombocytopenia, Th1 and Th17 cytokines, IL2-330, ILIRN VNTR

\section{To the editor}

According to the International Working Group consensus panel [1], primary Immune Thrombocytopenia (ITP) is defined as a peripheral blood platelet count less than $100 \times 10^{9} / \mathrm{L}$ in the absence of any obvious cause of thrombocytopenia. The recommendation of this value as the threshold for diagnosis of ITP, instead of the historical criteria of $150 \times 10^{9} / \mathrm{L}$, was first proposed by Rodeghiero et al. [2] based on the results of Stasi et al. [3] showing that healthy individuals with incidentally discovered platelet count between 100 and $150 \times 10^{9} / \mathrm{L}$ have a 10 -year probability of developing persistent thrombocytopenia of only $6.9 \%$ and of developing autoimmune disorders other than ITP of $12 \%$. However, in addition to the fact that this criterion has not been formally validated yet [4], patients with platelet count between 100 and $150 \times 10^{9} / \mathrm{L}$ remain without a diagnosis [5]. Recently, our group evaluated the serum cytokine profile of 98 patients with chronic ITP (platelet less than $100 \times 10^{9} / \mathrm{L}$ ) [6] attending the University Hospital, Universidade Federal de Minas Gerais, Brazil and demonstrated higher levels of Th17 cell-related

\footnotetext{
* Correspondence: dqueiroz@medicina.ufmg.br

'Laboratory of Research in Bacteriology, Faculdade de Medicina, Universidade Federal de Minas Gerais, Av. Alfredo Balena, 190, sala 216, 30130-100, Belo Horizonte, Brazil

Full list of author information is available at the end of the article
}

cytokines, in addition to Th1-associated cytokines in the patients than in blood donor controls. We have also demonstrated [7] that IL1RN VNTR and IL2-330 allele polymorphisms were associated with increased concentrations of IL-1 $\beta$ and of IL-2, respectively and were risk factors for chronic ITP. In this study, we compared serum Th1 and Th17 cytokine profile of 28 individuals (13 female and 15 male, mean age 49.2 years, range from 19 to 79 years) with persistent borderline thrombocytopenia with that of chronic ITP patients and controls we have previously evaluated [6]. None of the included individuals had obvious predisposing conditions or factors associated with thrombocytopenia. The platelet count of the subjects ranged from 101 to $138 \times 10^{9} / \mathrm{L}$ with a mean $( \pm \mathrm{SD})$ of 120 $( \pm 10) \times 10^{9} / \mathrm{L}$ and the duration of the thrombocytopenia varied from one to 12 years with a mean $( \pm \mathrm{SD})$ of 4.7 $( \pm 3.6)$ years. The serum cytokine concentrations (picogram per milliliter, $\mathrm{pg} / \mathrm{mL}$ ) were assayed in duplicate by ELISA (Biosource, Camarillo, CA). This study was approved by the Ethics Committee of the Institution and informed consent was obtained from all subjects. Data were analyzed with SPSS software package version 17.0 (SPSS Inc., Chicago, IL) and as the data showed significant departures from normality even after log transformation, comparisons among the groups were done by the two- 

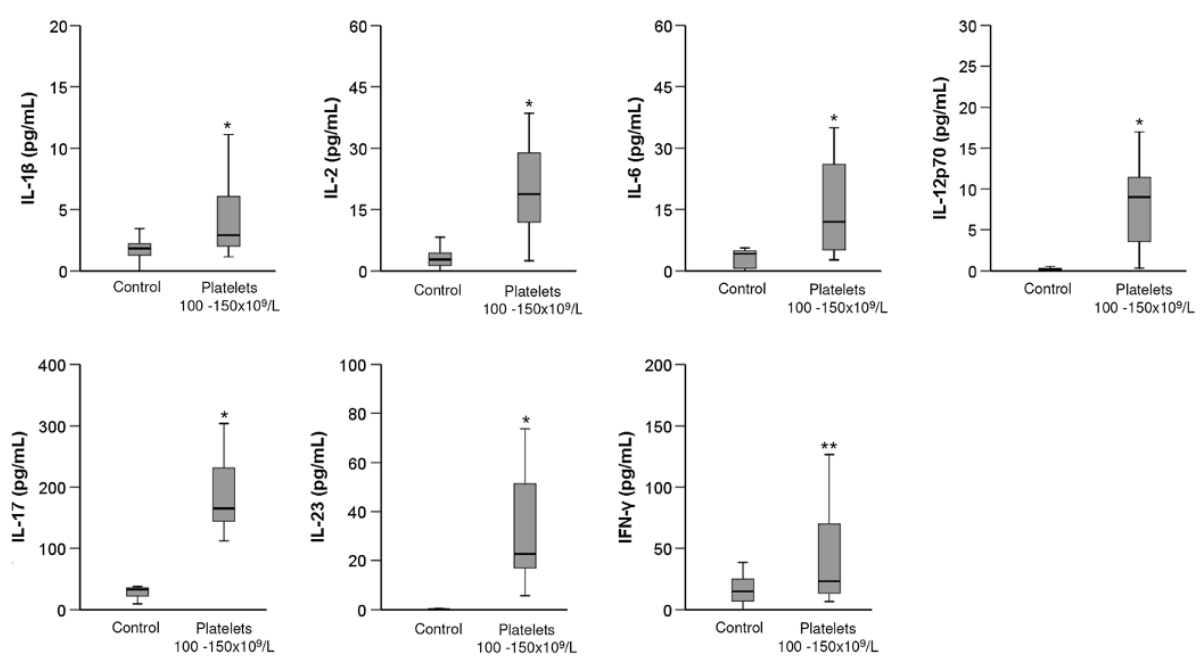

Figure 1 Box plots representing the serum levels $(\mathrm{pg} / \mathrm{mL})$ of IL-1 $\beta$, IL-2, IL-6, IL-12p70, IL-17, IL-23 and IFN- $\gamma$ in individuals with platelet count between 100 and $150 \times 10^{9} / L(n=28)$ and controls $(\mathbf{n}=\mathbf{1 5 0})$. The upper and lower limits of the boxes represent the $75^{\text {th }}$ and $25^{\text {th }}$ percentiles, respectively; the horizontal bar across the box indicated the median, and the ends of the vertical lines indicate the minimum and maximum data values $* p<10^{-3} ; * * p=0.001$.

tailed Mann-Whitney U-test. The level of significance was set at $\mathrm{p} \leq 0.05$.

Of note, the cytokine profile of the studied individuals with platelet count between 100 and $150 \times 10^{9} / \mathrm{L}$ did not differ from that of ITP patients we have previously studied [6] (IL-17A: 165.0 vs. $169.0 \mathrm{pg} / \mathrm{mL}, \mathrm{p}=0.55$; IL-1 2.9 vs. $3.5 \mathrm{pg} / \mathrm{mL}, \mathrm{p}=0.40$; IL-6: 11.9 vs. $14.0 \mathrm{pg} / \mathrm{mL}$, $\mathrm{p}=0.32$; IL-23: 22.6 vs. $17.7 \mathrm{pg} / \mathrm{mL}, \mathrm{p}=0.10$; IL-2: 18.7 vs. $17.3 \mathrm{pg} / \mathrm{mL}, \mathrm{p}=0.71 ;$ IFN- $\gamma: 23.4$ vs. $24.7 \mathrm{pg} / \mathrm{mL}$, $\mathrm{p}=0.84$; and IL-12p70: 9.0 vs. $7.3 \mathrm{pg} / \mathrm{mL}, \mathrm{p}=0.46$, respectively), but was significantly different from the cytokine profile observed in the healthy blood donors (Figure 1). A 6.3-fold increased serum level of IL-17A, the signature pro-inflammatory cytokine of the Th17 cell, and a 2.5-, 5.0-, and 85.6-fold increased of IL-1 $\beta$, IL-6 and IL-23, Th17-associated cytokines $\left(\mathrm{p}<10^{-3}\right.$ for all) were observed in the studied group when compared with the control group (Figure 1). Upregulation of the Th1 cytokines characterized by increased levels of IL-2 (6.3-fold increased, $\mathrm{p}<10^{-3}$ ), IL-12 p70 (31.0-fold increased, $\left.\mathrm{p}<10^{-3}\right)$ and IFN- $\gamma \quad(2.8$-fold increased, $\mathrm{p}=0.001$ ) were also observed (Figure 1). Also, the patients with ITP and individuals with platelet count between 100 and $150 \times 10^{9} / \mathrm{L}$ did not differ in respect to the mean age $(\mathrm{p}=0.32)$, gender $(\mathrm{p}=0.20)$ and duration of thrombocytopenia $(\mathrm{p}=0.82)$. Here we also reanalyzed the data of cytokine gene polymorphisms of 122 patients with platelet count bellow $150 \times 10^{9} / \mathrm{L}$ published elsewhere [7] by stratifying the group into those with platelet count less than $100 \times 10^{9} / \mathrm{L}$ and those with platelets between 100 and $150 \times 10^{9} / \mathrm{L}$. The presence of at least one allele 2 of ILIRN and one G polymorphic allele of IL2-330 was more frequently observed in the group of subjects with platelet count between 100 and $150 \times 10^{9} / \mathrm{L}$ ( $\mathrm{p}=0.04$ and $\mathrm{p}=0.03$, respectively) than in the controls, as well as in the patients with platelets less than $100 \times$ $10^{9} / \mathrm{L}(\mathrm{p}=0.007$ and $\mathrm{p}=0.02$, respectively) than in the controls, but they did not differ between the patient groups $(\mathrm{p}=0.8$ and $\mathrm{p}=0.7$ for $I L 1 R N$ and $I L 2$ polymorphisms, respectively). The polymorphisms were associated with enhanced concentration of IL-1 $\beta$ (6.3 vs. $2.5 \mathrm{pg} / \mathrm{mL}, \mathrm{p}=0.002)$ and IL-2 (22.8 vs. $14.9 \mathrm{pg} / \mathrm{mL}$, $\mathrm{p}=0.02)$ in the IL1RN 2 and IL2-330G carriers, respectively, in the group of subjects with platelet count between 100 and $150 \times 10^{9} / \mathrm{L}$. Also, in the patients with platelet count less than $100 \times 10^{9} / \mathrm{L}$, increased serum concentrations of IL-1 $\beta$ ( 6.3 vs. $\left.2.8 \mathrm{pg} / \mathrm{mL}, \mathrm{p}<10^{-3}\right)$ and IL-2 (22.6 vs. $14.8 \mathrm{pg} / \mathrm{mL}, \mathrm{p}<10^{-2}$ ) were observed in the carriers of $I L 1 R N^{*} 2$ and IL2-330G polymorphic alleles, respectively. In conclusion, individuals with platelet count between 100 and $150 \times 10^{9} / \mathrm{L}$ have enhanced levels of proinflammatory cytokines linked to Th1 and Th17 cell response, and are more frequently carriers of polymorphisms in genes that encode cytokines involved in the commitment of Th1 and Th17 immune response, similarly to that observed in patients with chronic ITP, which points to the need of a careful follow-up of this group of individuals and to search for pathogenic mechanisms associated with this condition.

\section{Competing interests}

The authors declare that they have no competing interests.

\section{Authors' contributions}

AMCR and DMMQ were the principal investigators and take primary responsibility for this paper; AMCR and DMMQ designed the study, done the statistical analysis and wrote the paper. CS, NCDC and MCAM recruited the 


\section{Grants}

This work was supported by Fundação de Amparo a Pesquisa de Minas Gerais (FAPEMIG) and Conselho Nacional de Desenvolvimento Científico e Tecnolológico (CNPq), Brazil.

Dr. Dulciene MM Queiroz is funded under The Sixth Framework Program of the European Union, Project CONTENT (INCO-CT-2006-032136).

\section{Author details}

'Laboratory of Research in Bacteriology, Faculdade de Medicina, Universidade Federal de Minas Gerais, Av. Alfredo Balena, 190, sala 216, 30130-100, Belo Horizonte, Brazil. ' ${ }^{2}$ Hematology Service, University Hospital, Universidade Federal de Minas Gerais, Belo Horizonte, Brazil. ${ }^{3}$ Department of Microbiology, Instituto de Ciências Biológicas, Universidade Federal de Minas Gerais, Belo Horizonte, Brazil. ${ }^{4}$ Departament of Internal Medicine, Faculdade de Medicina, Universidade Federal de Minas Gerais, Belo Horizonte, Brazil.

Received: 20 March 2013 Accepted: 8 April 2013

Published: 12 April 2013

\section{References}

1. Provan D, Stasi R, Newland AC, Blanchette VS, Bolton-Maggs P, Bussel JB, Chong BH, Cines DB, Gernsheimer TB, Godeau B, Grainger J, Greer I, Hunt BJ, Imbach PA, Lyons G, McMillan R, Rodeghiero F, Sanz MA, Tarantino M, Watson S, Young J, Kuter D: International consensus report on the investigation and management of primary immune thrombocytopenia. Blood 2010, 115:168-186.

2. Rodeghiero F, Stasi R, Gernsheimer T, Michel M, Provan D, Arnold DM Bussel JB, Cines DB, Chong BH, Cooper N, Godeau B, Lechner K, Mazzucconi MG, McMillan R, Sanz MA, Imbach P, Blanchette V, Kühne T, Ruggeri M, George JN: Standardization of terminology, definitions and outcome criteria in immune thrombocytopenic purpura of adults and children: report form an international working group. Blood 2009, 113:2386-2393.

3. Stasi R, Amadori S, Osborn J, Newland AC, Provan D: Long-term outcome of otherwise healthy individuals with incidentally discovered borderline thrombocytopenia. Plos Medicine 2006, 3:388-394.

4. Neunert C, Lim W, Crowther M, Cohen A, Solberg L Jr, Crowther MA: The American Society of Hematology 2011 evidence-based practice guideline for immune thrombocytopenia. Blood 2011, 117:4190-4207.

5. Grace RF, Long M, Kalish LA, Neufeld EJ: Applicability of 2009 international consensus terminology and criteria for immune thrombocytopenia to a clinical pediatric population. Pediatr Blood Cancer 2012, 58:216-220.

6. Rocha AMC, Souza C, Rocha GA, Melo FF, Clementino NCD, Marino MCA Bozzi A, Silva ML, Martins-Filho OA, Queiroz DMM: The levels of IL-17A and of the cytokines involved in the Th17 cell commitment are increased in patients with chronic Immune Thrombocytopenia. Haematologica 2011, 96:1560-1564

7. Rocha AMC, Souza C, Rocha GA, Melo FF, Saraiva ISB, Clementino NCD, Marino MCA, Queiroz DMM: ILIRN VNTR and IL2-330 polymorphic genes are independently associated with chronic immune thrombocytopenia. Br J Haematol 2010, 150:679-684.

doi:10.1186/1756-8722-6-28

Cite this article as: Rocha et al:: The serum levels of the cytokines involved in the Th17 and Th1 cell commitment are increased in individuals with borderline thrombocytopenia. Journal of Hematology \& Oncology 2013 6:28.

\section{Submit your next manuscript to BioMed Central and take full advantage of:}

- Convenient online submission

- Thorough peer review

- No space constraints or color figure charges

- Immediate publication on acceptance

- Inclusion in PubMed, CAS, Scopus and Google Scholar

- Research which is freely available for redistribution
C Biomed Central 